\title{
Leaf Microbiota of Strawberries as Affected by Biological Control Agents
}

\author{
Justine Sylla, Beatrix W. Alsanius, Erika Krüger, Annette Reineke, Stephan Strohmeier, and Walter Wohanka
}

First, third, fourth, and sixth authors: Geisenheim University, Von-Lade-Str. 1, DE-65366 Geisenheim, Germany; first and second authors: Swedish University of Agricultural Sciences, Department of Biosystems and Technology, P.O. Box 103, SE-23053 Alnarp, Sweden; and fifth author: FreshX Consulting \& Development, Walldorferstraße 26, DE-69226 Nußloch, Germany. Accepted for publication 13 May 2013.

\begin{abstract}
Sylla, J., Alsanius, B. W., Krüger, E., Reineke, A., Strohmeier, S., and Wohanka, W. 2013. Leaf microbiota of strawberries as affected by biological control agents. Phytopathology 103:1001-1011.

The increasing use of biological control agents (BCAs) against Botrytis cinerea in strawberry raises the question of whether there are any undesirable impacts of foliar applications of BCAs on nontarget microorganisms in the phyllosphere. Therefore, our objective was to investigate this issue within a field study. Strawberry plants were repeatedly sprayed with three BCAs—namely, RhizoVital 42 fl. (Bacillus amyloliquefaciens FZB42), Trianum-P (Trichoderma harzianum T22), and Naturalis (Beauveria bassiana ATCC 74040)— to suppress Botrytis cinerea infec-

using plate counts and pyrosequencing and compared with the microbial community of nontreated leaves. Plate count results indicate that the applied Bacillus and Trichoderma spp. survived in the strawberry phyllosphere throughout the strawberry season. However, no significant impacts on the leaf microbiota could be detected by this culture-dependent technique. Pyrosequencing of internal transcribed spacer ribosomal RNA and 16S RNA sequences revealed a change in fungal composition and diversity at class level after the introduction of T. harzianum T22 to the phyllosphere, whereas the bacterial composition and diversity was not affected by either this Trichoderma preparation or the other two BCAs. Our results suggest that pyrosequencing represents a useful method for studying microbial interactions in the phyllosphere.
\end{abstract} tions. Microbial communities of differentially treated leaves were analyzed
Gray mold, caused by Botrytis cinerea Pers., is one of the most important diseases in strawberry, causing severe pre- and postharvest losses worldwide $(9,23,41)$. Rising concerns of consumers about pesticide use, the increasing occurrence of fungicideresistant $B$. cinerea strains in conventional strawberry production (47), and the restricted use of fungicides in organic strawberry production (26) brought a growing demand for alternative control measures. The use of biological control agents (BCAs) offers a promising alternative or supplement to fungicides for the control of $B$. cinerea in strawberry. In various studies, several BCAs such as Bacillus subtilis and Trichoderma harzianum have shown significant efficacies toward Botrytis cinerea in strawberry $(12,14$, 17,21).

In terms of safety, BCAs should not have any effects on nontarget organisms, which include toxicity and pathogenicity to and displacement of nontarget microorganisms (7). According to ecological concepts, however, immigration into and colonization of the phyllosphere is highly dependent on the competitiveness of BCAs as well as their ability to adapt to this habitat $(28,48)$. For this reason, competitive BCAs might eventually harm not only pathogenic microorganisms but also nontarget organisms; for instance, through displacement or toxicity. There have been rising concerns by Brimmer and Boland (5) that fungal BCAs in particular, including Trichoderma spp., might pose a risk to nontarget microorganisms. They hypothesized that changes in the indigenous soil microbiota might disturb entire ecosystems and, in turn, have significant impacts on the environment. Several studies have been conducted to investigate nontarget effects of BCAs on soil microbial communities $(15,36-38)$. None of these, however, con-

Corresponding author: J. Sylla; E-mail address: Justine.Sylla@hs-gm.de

http://dx.doi.org/10.1094/PHYTO-01-13-0014-R

(C) 2013 The American Phytopathological Society firmed long-lasting effects of applied BCAs on the indigenous soil microbiota.

Because there are only few studies investigating the impact of foliar BCA applications on the indigenous leaf microbiota $(20,30,35,51)$, we addressed this issue in a field study. Several BCAs were applied as single-strain and multiple-strain treatments to the phyllosphere of field-grown strawberry to control $B$. cinerea, in which the leaves accounted for the biggest treated area. The leaf microbiota of differentially treated plants was analyzed by two complementary techniques; namely, plate counts and pyrosequencing. The objective of this study was to test the hypothesis that introduced BCAs have no significant impact on the nonpathogenic leaf microbiota of strawberry, regardless of whether applied as single-strain or multiple-strain treatments.

\section{MATERIALS AND METHODS}

Experimental design. In the beginning of August 2009, strawberry plants (Fragaria $\times$ ananassa Duch. 'Elsanta') were planted in a field located in Geisenheim (Hesse, Germany). Plants were drip irrigated $\left(9.79\right.$ liter $\left.\mathrm{m}^{-1}\right)$ when soil-moisture tension was below $-250 \mathrm{hPa}$ and were mulched with straw on 17 May 2010. Weeds were removed when required, whereas no measures were done for pest and disease control, except for the treatments described below. Strawberry plants were arranged in a randomized block design with 36 plots, each consisting of 80 plants.

Three commercially available biological control agents were used in the present study: RhizoVital $42 \mathrm{fl}$. (contains Bacillus amyloliquefaciens FZB42 at $2.5 \times 10^{10}$ endospores $\mathrm{ml}^{-1}$ ) (ABiTEP GmbH) Trianum-P (contains T. harzianum T22 at $1 \times$ $10^{9}$ conidia $\mathrm{g}^{-1}$ ) (Koppert Biological Systems), and Naturalis (contains the entomopathogenic fungus Beauveria bassiana ATCC 74040 at $2.3 \times 10^{7}$ conidia $\mathrm{ml}^{-1}$ ) (Intrachem Bio Deutschland $\mathrm{GmbH} \& \mathrm{Co}$. KG). From flowering through harvest in 2010, 
strawberry plants were treated on 29 April; 10, 18, and 25 May; and 1, 14, and 22 and June with these BCAs against Botrytis cinerea according to the manufacturer's instructions in single- or multiple-strain treatments (RhizoVital 42 fl. + Trianum-P, RhizoVital 42 fl. + Naturalis, Trianum-P + Naturalis, and RhizoVital 42 fl. + Trianum-P + Naturalis). Control plots were treated with either water or fungicides; that is, Signum on 29 April (boscalid at $267 \mathrm{~g} \mathrm{~kg}^{-1}$ and pyraclostrobin at $67 \mathrm{~g} \mathrm{~kg}^{-1}$ ), Switch on 10 May (cyprodinil at $375 \mathrm{~g} \mathrm{~kg}^{-1}$ and fludioxonil at $250 \mathrm{~g} \mathrm{~kg}^{-1}$ ), and Teldor (fenhexamid at $510 \mathrm{~g} \mathrm{~kg}^{-1}$ ) + Ortiva (azoxystrobin at $250 \mathrm{~g} \mathrm{liter}^{-1}$ ) on 18 May. Each treatment was applied in four replicates. For creating favorable conditions for B. cinerea infections, plants were overhead-irrigated (2 to $5 \mathrm{~mm}$ ) at night from flowering through harvest. Additionally, 70 of 80 plants were not harvested in each plot in order to enhance disease incidence. Ten (not harvested) plants per plot were labeled and used for the assessments of gray mold incidence according to the following equation:

$$
\text { Incidence of Botrytis cinerea }(\%)=\left(n_{\text {Bot }} / n_{\text {total }}\right) \times 100
$$

where $n_{B o t}=$ number of infected fruit plant $^{-1}$ and $n_{\text {total }}=$ total number of fruit plant ${ }^{-1}$.

The disease assessments were conducted at different phenological growth stages according to the $\mathrm{BBCH}$ identification key of strawberry (27); that is, on 8 June $(\mathrm{BBCH} 85), 16$ June $(\mathrm{BBCH}$ 87 ), and 22 June (BBCH 89) 2010, respectively. The disease reduction was calculated as follows:

$$
\text { Disease reduction }(\%)=\left(d_{t} / d_{c}\right) \times 100
$$

where $d_{t}=$ disease incidence of the treatment and $d_{c}=$ disease incidence of the control.

Sample collection and microbe extraction. To determine the microbial composition of the strawberry phyllosphere, one leaf per plant was carefully collected from 30 plants in every plot on 22 April 2010 (7 days before BCA introduction; BBCH 59), 11 May 2010 (BBCH 65), and 27 May 2010 (BBCH 78), transferred into plastic bags, and stored on ice until sample collection was completed. Leaf samples were transported to the laboratory, weighed, and transferred into sterile glass flasks $(250 \mathrm{ml})$. Aliquots of $230 \mathrm{ml}$ of phosphate-buffered saline buffer $(\mathrm{NaCl}$ at $8 \mathrm{~g}$ liter ${ }^{-1}, \mathrm{KCl}$ at $0.2 \mathrm{~g} \mathrm{liter}^{-1}, \mathrm{Na}_{2} \mathrm{HPO}_{4}$ at $1.44 \mathrm{~g} \mathrm{liter}^{-1}, \mathrm{KH}_{2} \mathrm{PO}_{4}$ at $0.24 \mathrm{~g} \mathrm{liter}^{-1}$, and $\mathrm{pH}=7.4$ ) were added to each flask. The flasks were shaken with an overhead shaker at $\approx 50 \mathrm{rpm}$ for $30 \mathrm{~min}$ followed by ultrasonification for $7 \mathrm{~min}$ at $35 \mathrm{kHz}$ (Bandelin Sonorex Super RK510H). The wash solutions were then transferred into 250-ml centrifuge flasks.

Plate counts. Aliquots of $50 \mu \mathrm{l}$ from each wash solution (undiluted) were spiral plated (Whitley Automatic Spiral Plater; Don Whitley Scientific, England) on potato dextrose agar at $10.0 \mathrm{~g} \mathrm{liter}^{-1}$ (Merck, Germany), Bacto agar at $12.0 \mathrm{~g} \mathrm{liter}^{-1}$ (BD, France), streptomycin sulfate at $0.1 \mathrm{~g} \mathrm{liter}^{-1}$, tetracycline hydrochloride at $0.01 \mathrm{~g} \mathrm{liter}^{-1}$, and R2A (Difco R2A agar at $18.2 \mathrm{~g} \mathrm{liter}^{-1}$ [BD] and cycloheximide at $0.1 \mathrm{~g} \mathrm{liter}^{-1}$ ) to determine the CFU of total fungi and total bacteria. The amount of endospore-forming bacteria (e.g., bacilli) was determined by heating $5 \mathrm{ml}$ of each wash solution to $80^{\circ} \mathrm{C}$ for $15 \mathrm{~min}$ and plating it on Difco tryptic soy agar at $4.0 \mathrm{~g} \mathrm{liter}^{-1}$ (BD), Bacto agar at $13.5 \mathrm{~g} \mathrm{liter}^{-1}$ (BD), and cycloheximide at $0.1 \mathrm{~g} \mathrm{liter}^{-1}$. The CFU of Trichoderma spp. and Beauveria bassiana were determined by plating $50 \mu \mathrm{l}$ of each wash solution onto selective media as follows: Bacto agar at $20.0 \mathrm{~g} \mathrm{liter}^{-1}$ (BD), glucose $\cdot \mathrm{H}_{2} \mathrm{O}$ at $3.3 \mathrm{~g} \mathrm{liter}^{-1}, \mathrm{~K}_{2} \mathrm{HPO}_{4}$ at $0.9 \mathrm{~g}$ liter ${ }^{-1}, \mathrm{KCl}$ at $0.15 \mathrm{~g} \mathrm{liter}^{-1}, \mathrm{MgSO}_{4} \cdot 7 \mathrm{H}_{2} \mathrm{O}$ at $0.2 \mathrm{~g} \mathrm{liter}^{-1}$, $\mathrm{NH}_{4} \mathrm{NO}_{3}$ at $1.0 \mathrm{~g} \mathrm{liter}^{-1}$, rose Bengal at $2 \mathrm{ml} \mathrm{liter}^{-1}$, and streptomycin sulfate at $0.3 \mathrm{~g} \mathrm{liter}^{-1}$ for Trichoderma spp.; and Bacto agar at $18.0 \mathrm{~g} \mathrm{liter}^{-1}$ (BD), glucose at $20.0 \mathrm{~g} \mathrm{liter}^{-1}$, soya peptone at
$10.0 \mathrm{~g} \mathrm{liter}^{-1}$, cycloheximide at $0.05 \mathrm{~g} \mathrm{liter}^{-1}$, dodine at $0.1 \mathrm{~g} \mathrm{liter}^{-1}$, streptomycin sulfate at $0.1 \mathrm{~g} \mathrm{liter}^{-1}$, and tetracycline hydrochloride at $0.05 \mathrm{~g} \mathrm{liter}^{-1}$ for $B$. bassiana.

DNA isolation and pyrosequencing. The remaining wash solutions were centrifuged at $14,000 \times g$ at $4^{\circ} \mathrm{C}$ for $20 \mathrm{~min}$ and the supernatant was discarded. Using a Power Soil DNA Isolation Kit (Sued-Laborbedarf $\mathrm{GmbH}$, Gauting, Germany), genomic DNA was extracted from the resulting pellet according to the manufacturer's instructions. Fragments of the fungal internal transcribed spacer ribosomal RNA (ITS rRNA) gene $(\approx 400 \mathrm{bp}$ ) and bacterial $16 \mathrm{~S}$ rRNA gene $(\approx 450 \mathrm{bp})$ were amplified using the universal primer pairs ITS1 (5'-CTTGGTCATTTAGAGGAAG TAA-3') and ITS2 (5'-GCTGCGTTCTTCATCGATGC-3') (6) as well as $27 \mathrm{~F}$ ( $5^{\prime}$-MGAGTTTGATCCTGGCTCAG-3') and 337R (5'-GCTGCCTCCCGTAGGAGT-3') (16), respectively. For pyrosequencing, primers were modified by adding the GS FLX Titanium Key-Primers A (CGTATCGCCTCCCTCGCGCCA) and B (CTATGCGCCTTGCCAGCCCGC), a key sequence (TCAG), and a sample specific multiplex identifier sequence (MID). Primers with identical MID-tags were used for each sample replicate within one treatment from each sampling date. DNA amplification, however, was individually done for each sample replicate from each treatment and sampling date. The polymerase chain reaction (PCR) reaction mixtures consisted of $0.2 \mu \mathrm{l}$ of Dream

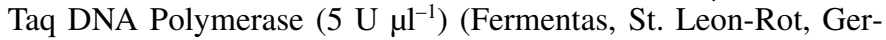
many), $2 \mu \mathrm{l}$ of $10 \times$ Dream Taq Buffer (Fermentas), $0.4 \mu \mathrm{l}$ of $10 \mathrm{mM}$ dNTPs (Fermentas), $1 \mu \mathrm{l}$ of 10 pmol primers, and $20 \mathrm{ng}$ of genomic DNA in a final volume of $20 \mu \mathrm{l}$. The PCR parameters used for fungal ITS rRNA and bacterial 16S rRNA amplification were according to Buée et al. (6) and Hirsch et al. (18), respectively. Aliquots of $4 \mu \mathrm{l}$ of each PCR product were loaded on a $1 \%$ agarose gel and tested for correct size. The PCR products were purified with HiYield PCR Clean-up/Gel Extraction Kit (SuedLaborbedarf GmbH). Fungal ITS rRNA and bacterial 16S rRNA PCR products, which have been individually generated from a total of 108 leaf samples, were pooled at equal molar concentrations and sent for pyrosequencing (LGC Genomics $\mathrm{GmbH}$, Berlin).

Taxonomic assignments. LGC Genomics provided MIDsorted and already clipped sequence reads which were then exploited for blast sequence analysis. BLAST (BLASTn 2.2.25+) was performed on National Center for Biotechnology Information NT Database (version of 12 May 2011) containing 16,031,302 sequences with the following parameters: word length, 28; gap open, 5; gap extension, 2; match, 1; mismatch, 3; E-value, 10; no dust filtering. Result files were then imported into the MetaGenome Analyzer (version 4.62.3; Daniel Huson, Tübingen, Germany) and species assignment was performed according to the following parameters for the LCA algorithm: minimum support, 1; minimum score, 35; top percent, 10; win score, 0 ; and minimum complexity, 0.3 .

Statistical analyses. Except for the calculation of diversity indices for pyrosequencing data, all data analyses were performed using the STATISTICA software package (version 7.1; StatSoft, Tulsa, OK). Because data of $B$. cinerea disease assessments and plate counts were not homogeneous in variance, nonparametric Kruskal-Wallis analyses of variance were performed for these data in order to detect differences between the treatments, followed by multiple comparisons using the Kruskal-Wallis test $(\alpha=0.05)$. Based on the relative abundances of ITS rRNA and $16 \mathrm{~S}$ rRNA sequences (percent reads) at class level, a principal component analysis (PCA) was performed to explore the composition of fungal and bacterial communities in different samples at class level. Nonparametric Wilcoxon-Tests were performed to pairwise compare the composition of ITS rRNA and 16S rRNA sequences in treated leaf samples with those in control samples at class level, respectively, with a Bonferroni correction for multiple comparisons (34) applied to all $P$ values $(\alpha=0.00625)$. The 
Shannon-Wiener diversity index and Simpson diversity index (1-D) were calculated for the relative abundances of ITS rRNA and 16S rRNA sequences at class level with BioToolKit 320 (Chang Bioscience Inc., Castro Valley, CA).

\section{RESULTS}

Incidence of Botrytis cinerea. At the first assessment date (BBCH 85), almost no infected fruit were apparent in the strawberry field (data not shown). At the second (BBCH 87) and third (BBCH 89) assessment dates, the Botrytis cinerea disease incidence was 7.0 to 14.5 and 21.6 to $37.5 \%$, respectively (Fig. 1). Compared with water treatments, applications with BCAs did not significantly reduce the incidence of $B$. cinerea at any developmental stage, whereas applications with fungicides significantly reduced incidence of $B$. cinerea by $32.5 \%$ at $\mathrm{BBCH} 89$.

Plate counts. According to plate counts, total bacteria $(2.6 \times$ $10^{4}$ CFU g dry weight $[\mathrm{DW}]^{-1}$ ) made up the main group of the indigenous culturable phyllosphere microbiota of strawberry prior to BCA applications (22 April 2010; BBCH 59), followed by endospore-forming bacteria $\left(1.8 \times 10^{3} \mathrm{CFU} \mathrm{g} \mathrm{DW}{ }^{-1}\right)$, total fungi $\left(6.8 \times 10^{2} \mathrm{CFU} \mathrm{g} \mathrm{DW}{ }^{-1}\right)$, and only a few Trichoderma spp. $(1.9 \times$ $10^{1} \mathrm{CFU} \mathrm{g} \mathrm{DW}^{-1}$ ). Beauveria spp. could not be found in the strawberry phyllosphere prior to introduction of BCAs using culture-dependent techniques (Fig. 2).

After the introduction of BCAs (BBCH 65 and $\mathrm{BBCH} 78$ ), plate counts of Trichoderma spp. were significantly increased in all samples obtained from plots treated with Trianum-P in both single- and multiple-strain treatments. For most of these treatments, however, the total number of culturable fungi was not significantly increased. Plate counts of entomopathogenic Beauveria spp. were not significantly increased in samples obtained from plots treated with Naturalis in either single- or multiplestrain treatments (Fig. 3).

Plate counts of endospore-forming bacteria were different at the two sampling dates after the introduction of BCAs. At the second sampling date (11 May 2010; BBCH 65), total numbers of bacteria were significantly enhanced in samples from plots treated with RhizoVital 42 fl., RhizoVital 42 fl. + Trianum-P, and RhizoVital 42 fl. + Trianum-P + Naturalis, whereas counts of endospore-forming bacteria were only significantly enhanced in samples from plots treated with RhizoVital 42 fl. in multiplestrain treatments (Fig. 3A). At the third sampling date (27 May 2010; BBCH 78), total numbers of bacteria were not increased in

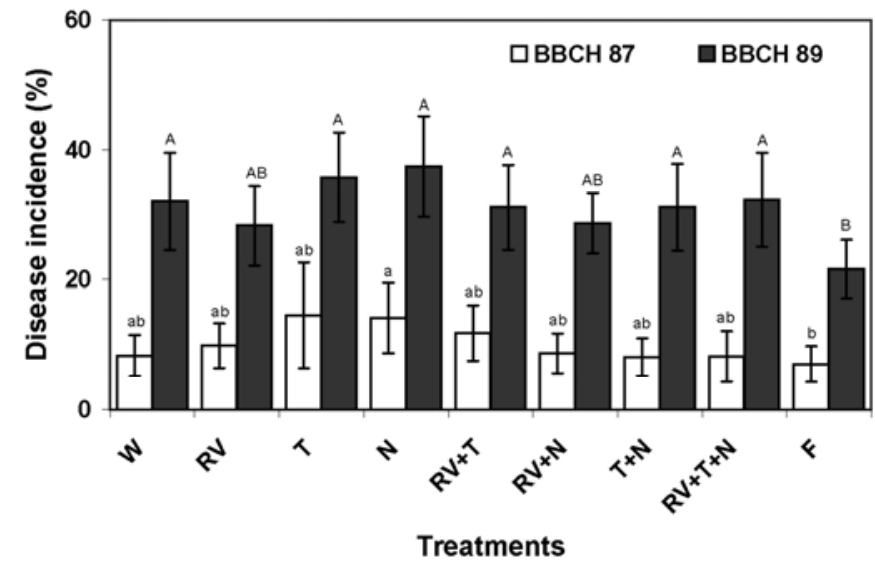

Fig. 1. Effects of biological control agent and fungicide treatments on the incidence of Botrytis cinerea (\%) at BBCH 87 (16 June 2010) and BBCH 89 (22 June 2010) under field conditions $(n=40)$. Treatments are indicated by $\mathrm{W}=$ water, $\mathrm{RV}=$ RhizoVital $42 \mathrm{fl}$., $\mathrm{T}=$ Trianum $-\mathrm{P}, \mathrm{N}=$ Naturalis, and $\mathrm{F}=$ fungicides. Error bars represent standard error of the mean values. Columns of each sampling date marked with the same letters are not significantly different according to Kruskal-Wallis-Test $(\alpha=0.05)$. all samples from plots treated with RhizoVital 42 fl. in single- and multiple-strain treatments, whereas counts of endospore-forming bacteria were significantly enhanced in these samples (Fig. 3B). Compared with control treatments, plate counts of total culturable fungi were not reduced by fungicide treatments at either the second (Fig. 3A) or third (Fig. 3B) sampling date.

When comparing plate counts of different sampling dates in the control samples, the amount of total bacteria and Trichoderma spp. increased from the first $(\mathrm{BBCH} 59)$ through the third $(\mathrm{BBCH}$ 78) sampling date. Plate counts of endospore-forming bacteria initially increased in the control samples from first sampling through the second sampling date $(\mathrm{BBCH} 65)$ but subsequently decreased at the third sampling. Plate counts of total fungi, however, only slightly differed between the three sampling dates (Figs. 2 and 3).

Pyrosequencing. In total, 50,835 ITS rRNA and 19,560 16S rRNA sequences were obtained from all strawberry leaf samples. From these, 34,045 ITS rRNA (67\%) and 8,425 16S rRNA (43.1\%) sequences could be assigned to fungi and bacteria, respectively. Thus, the number of fungal ITS rRNA sequences was approximately four times higher than the number of bacterial $16 \mathrm{~S}$ rRNA sequences. The number of total fungal ITS rRNA and bacterial 16S rRNA sequences differed among the three sampling dates, with the highest number of sequences obtained from the second sampling date (Table 1). The following results are consistently displayed at class level because the number of reads was in a reasonable proportion to the provided information at this taxonomic level, particularly for fungal ITS rRNA sequences.

Composition and biodiversity of fungal classes among different samples. A comparison of ITS rRNA profiles at class level prior to BCA introduction (22 April 2010; BBCH 59) revealed that initial composition of fungal communities was similar across all leaf samples (Table 2). The strawberry phyllosphere was mainly colonized by members of classes Tremellomycetes, Dothideomycetes, and Sordariomycetes. The composition of fungi (class level) in plots intended for subsequent BCA or fungicide treatments did not significantly differ from that in the control samples. However, leaf samples from plots intended for subsequent fungicide treatments were additionally colonized by members of classes Leotiomycetes (18.1\%), Agaricomycetes (10.6\%), and Microbotryomycetes $(10.7 \%)$. The extent of initial microbial biodiversity was similar among all leaf samples, with the ShannonWiener diversity index at 1.314 to 1.960 and the Simpson diversity index at 0.582 to 0.811 .

After the introduction of BCAs, fungal communities of the strawberry phyllosphere were composed of members of Sordariomycetes as the dominating class in all samples, followed by members of classes Dothideomycetes, Tremellomycetes, and Agarico-

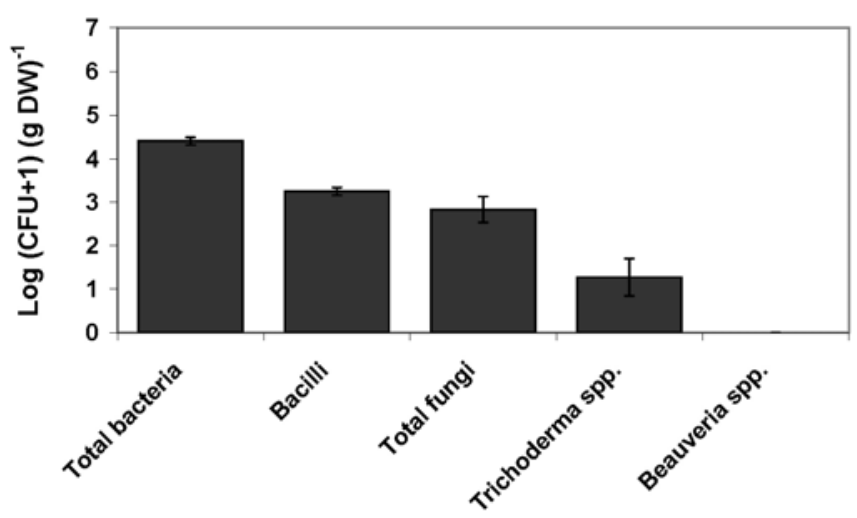

Fig. 2. Culturable microbial biota of the strawberry phyllosphere prior to the introduction of biological control agents (sampling on 22 April 2010; BBCH 59 ) as determined by plate counts (pooled data, $n=108$ ). Error bars represent standard error of the mean values. 
mycetes at the second sampling date (11 May 2010; BBCH 65) (Table 3). The relative abundance of members of class Letiomycetes, to which the pathogenic fungus $B$. cinerea can be assigned, was similar in all leaf samples (1.1 to $5 \%$ ). No significant changes of fungal composition resulted from applications with RhizoVital 42 fl. and Naturalis, whereas significant changes in the composition of fungal microbiota were evident in leaf samples previously treated with Trianum-P in both single- and multiplestrain treatments (each $P<0.001$ ). The relative abundance of class Sordariomycetes, which comprise the genera Trichoderma but also Beauveria, was no less than $77.9 \%$ in these samples and, thus, at least 1.6-fold higher than in the control samples $(48.9 \%)$. Accordingly, the relative abundance of other fungal classes such as Dothideomycetes (3.5 to 8.6\%) and Agaricomycetes (2.3 to $3 \%)$ was decreased as compared with the control samples $(19.8$ and $7.5 \%$, respectively). In these samples, the Shannon-Wiener (0.735 to 0.947$)$ and Simpson diversity (0.313 to 0.387$)$ indices were approximately two times lower than those of the control samples (1.699 and 0.707, respectively). This indicates that Trichoderma spp.-treated samples were less diverse at class level than control samples.

At the third sampling date (27 May 2010; BBCH 78), fungal communities mainly consisted of members of classes Tremellomycetes, Sordariomycetes, and Dothideomycetes. At this date, the relative abundance of class Letiomycetes was again similar in all leaf samples (0 to $2.7 \%$ ). At class level, the fungal communi-
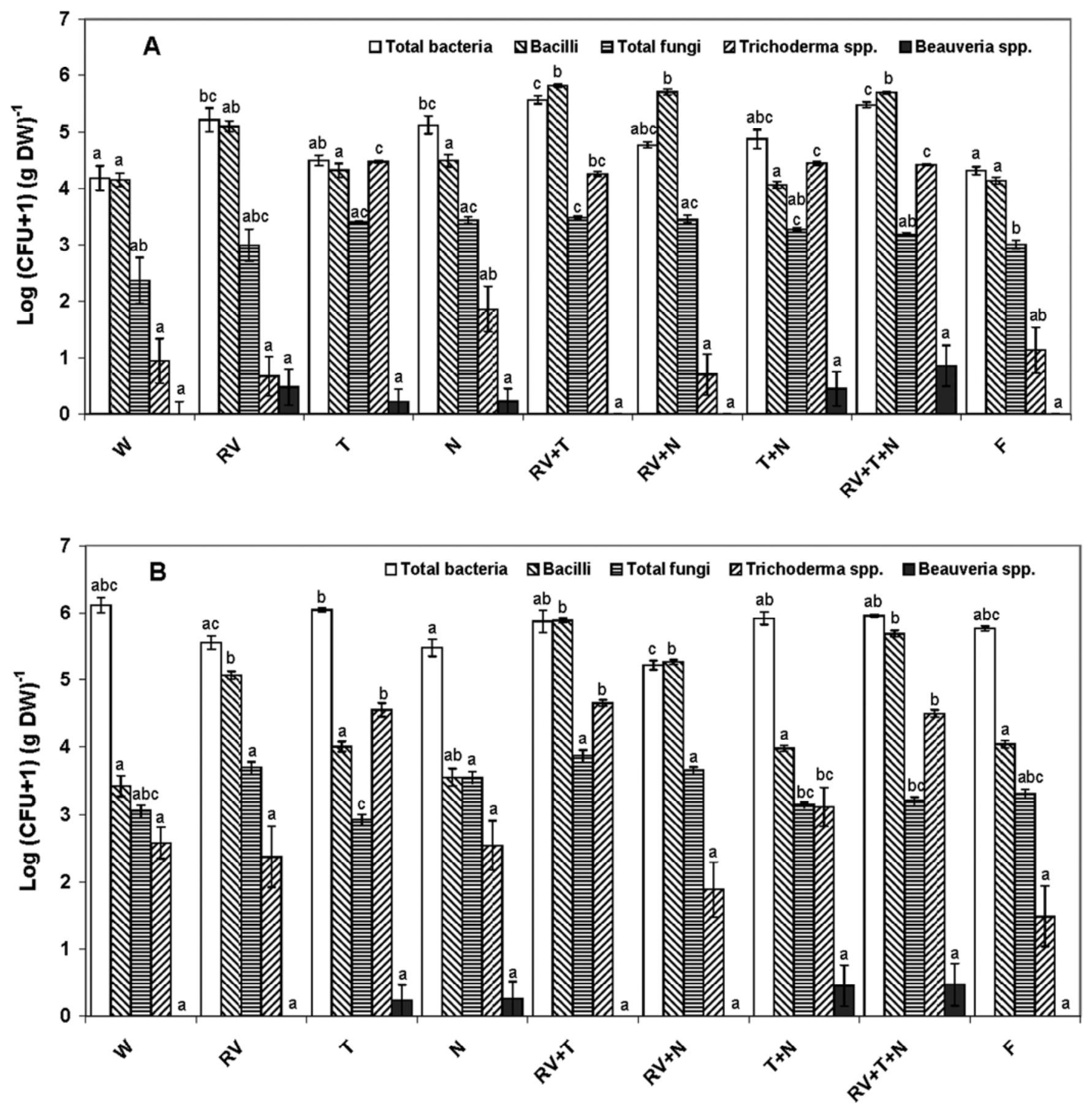

Fig. 3. Culturable microbial biota of the strawberry phyllosphere after introduction of different biological control agents at $\mathbf{A}$, the second sampling date (11 May 2010; $\mathrm{BBCH} 65)$ and $\mathbf{B}$, the third sampling date (27 May 2010; BBCH 78) as determined by plate counts (each $n=12)$. Treatments are indicated by $\mathrm{W}=$ water, $\mathrm{RV}=$ RhizoVital $42 \mathrm{fl}$., $\mathrm{T}=$ Trianum-P, $\mathrm{N}=$ Naturalis, and $\mathrm{F}=$ fungicides. Error bars represent standard error of the mean values. Columns marked with the same letters are not significantly different within each microbial group according to Kruskal-Wallis-Test $(\alpha=0.05)$. 
ties were as well significantly affected by previous applications with Trianum-P in most multiple-strain treatments (Table 4). In these samples, the relative abundance of class Sordariomycetes was at least approximately fourfold higher than in the control samples. Applications with Trianum-P as a single-strain treatment and the combined treatment with Trianum-P + Naturalis did not result in a significant change of fungal composition $(P=0.194$ and 0.008 , respectively), whereas applications with Naturalis as a

TABLE 1. Number of fungal internal transcribed spacer ribosomal RNA (ITS rRNA) and bacterial 16S rRNA sequences obtained at different sampling dates from the microbiota of strawberry leaves ${ }^{\mathrm{a}}$

\begin{tabular}{|c|c|c|c|c|c|c|}
\hline \multirow[b]{3}{*}{ Number of sequences } & \multicolumn{6}{|c|}{ Sampling date (2010) } \\
\hline & \multicolumn{3}{|c|}{ ITS rRNA sequences assigned to fungi } & \multicolumn{3}{|c|}{ 16S rRNA sequences assigned to bacteria } \\
\hline & $\begin{array}{c}22 \text { April } \\
(\text { BBCH 59) }\end{array}$ & $\begin{array}{c}11 \text { May } \\
(\text { BBCH 65) }\end{array}$ & $\begin{array}{c}27 \text { May } \\
(\mathrm{BBCH} 78)^{\mathrm{c}}\end{array}$ & $\begin{array}{c}22 \text { April } \\
(\text { BBCH 59) }\end{array}$ & $\begin{array}{c}11 \text { May } \\
(\text { BBCH 65) }\end{array}$ & $\begin{array}{c}27 \text { May } \\
(\mathrm{BBCH} 78)^{\mathrm{c}}\end{array}$ \\
\hline Total & 9,568 & 17,012 & 7,465 & 1,550 & 5,221 & 1,654 \\
\hline Averaged per sample ${ }^{d}$ & $1,063 \pm 292$ & $1,890 \pm 401$ & $829 \pm 194$ & $172 \pm 206$ & $580 \pm 713$ & $184 \pm 144$ \\
\hline
\end{tabular}

a BBCH numbers indicate phenological growth stages and BBCH-identification keys of strawberry according to Meier et al. (27).

${ }^{\mathrm{b}}$ Sampling prior to biological control agent (BCA) introduction.

${ }^{\mathrm{c}}$ Sampling after BCA introduction.

${ }^{\mathrm{d}}$ Number of samples per sampling date $=9$.

TABLE 2. Composition of fungal communities (class level) in the strawberry phyllosphere prior to the introduction of biological control agents (sampling on 22 April 2010; BBCH 59) ${ }^{\mathrm{a}}$

\begin{tabular}{|c|c|c|c|c|c|c|c|c|c|}
\hline \multirow[b]{2}{*}{ Fungal classes $^{\mathrm{b}}$} & \multicolumn{9}{|c|}{ Relative abundance of fungal classes $(\%)$ in different leaf samples } \\
\hline & $\mathrm{W}$ & RV & $\mathrm{T}$ & $\mathrm{N}$ & $\mathrm{RV}+\mathrm{T}$ & $\mathrm{RV}+\mathrm{N}$ & $\mathrm{T}+\mathrm{N}$ & $\mathrm{RV}+\mathrm{T}+\mathrm{N}$ & $\mathrm{F}$ \\
\hline Tremellomycetes & 57.3 & 57.9 & 48.7 & 54.9 & 50.2 & 52.2 & 48.9 & 61.4 & 33.8 \\
\hline Dothideomycetes & 14.8 & 19.1 & 23.2 & 14.7 & 14.8 & 20.0 & 22.5 & 18.1 & 11.6 \\
\hline Sordariomycetes & 7.2 & 6.9 & 9.5 & 12.2 & 15.1 & 11.5 & 12.8 & 8.2 & 3.8 \\
\hline Leotiomycetes & 3.2 & 2.2 & 2.4 & 2.8 & 2.8 & 2.1 & 2.1 & 1.4 & 18.1 \\
\hline Lecanoromycetes & 5.5 & 5.2 & 4.6 & 5.0 & 3.6 & 4.8 & 2.9 & 2.2 & 0.7 \\
\hline Eurotiomycetes & 5.2 & 3.7 & 4.6 & 4.1 & 4.7 & 2.3 & 3.2 & 3.3 & 1.7 \\
\hline Agaricomycetes & 1.7 & 1.5 & 1.9 & 1.7 & 2.3 & 2.0 & 1.4 & 0.0 & 10.6 \\
\hline Cystobasidiomycetes & 2.2 & 1.1 & 2.4 & 2.0 & 2.4 & 2.4 & 2.9 & 2.2 & 3.0 \\
\hline Microbotryomycetes & 0.7 & 1.1 & 0.5 & 0.6 & 1.1 & 0.5 & 0.5 & 0.5 & 10.7 \\
\hline Taphrinomycetes & 1.1 & 0.7 & 1.2 & 0.4 & 0.7 & 0.9 & 0.8 & 0.8 & 0.7 \\
\hline Agaricostilbomycetes & 0.1 & 0.2 & 0.7 & 0.4 & 0.7 & 0.5 & 1.3 & 1.4 & 0.3 \\
\hline Saccharomycetes & 0.2 & 0.0 & 0.1 & 0.2 & 0.5 & 0.2 & 0.2 & 0.0 & 3.9 \\
\hline Chytridiomycetes & 0.4 & 0.2 & 0.0 & 0.4 & 0.5 & 0.4 & 0.3 & 0.3 & 0.1 \\
\hline Pezizomycetes & 0.4 & 0.0 & 0.1 & 0.5 & 0.2 & 0.2 & 0.0 & 0.3 & 0.7 \\
\hline Shannon-Wiener diversity index & 1.522 & 1.411 & 1.586 & 1.539 & 1.660 & 1.534 & 1.580 & 1.314 & 1.960 \\
\hline Simpson diversity index & 0.638 & 0.618 & 0.694 & 0.656 & 0.697 & 0.670 & 0.691 & 0.582 & 0.811 \\
\hline$P^{\mathrm{c}}$ & $\ldots$ & 0.898 & 0.623 & 0.918 & 0.169 & 0.135 & 0.423 & 0.761 & 0.022 \\
\hline
\end{tabular}

a Average number of sequences per sample was $718 \pm 208$. Treatments: $\mathrm{W}=$ water, $\mathrm{RV}=$ RhizoVital $42 \mathrm{fl}$., $\mathrm{T}=$ Trianum- $\mathrm{P}, \mathrm{N}=\mathrm{Naturalis}$, and $\mathrm{F}=$ fungicides .

${ }^{\mathrm{b}}$ Internal transcribed spacer ribosomal RNA (ITS rRNA) sequences assigned to fungal classes (classes with $>1 \%$ in total are displayed).

${ }^{c} P$ values for pairwise Wilcoxon-Tests comparing the composition of fungal ITS rRNA sequences in treated leaf samples with that of control samples (W). No significant differences were evident in the composition of fungal ITS rRNA sequences as compared with control treatment $(\alpha=0.00625)$.

TABLE 3. Composition of fungal communities (class level) in the strawberry phyllosphere after the introduction of biological control agents (sampling on 11 May 2010; BBCH 65)

\begin{tabular}{|c|c|c|c|c|c|c|c|c|c|}
\hline \multirow[b]{2}{*}{ Fungal classes ${ }^{\mathrm{b}}$} & \multicolumn{9}{|c|}{ Relative abundance of fungal classes $(\%)$ in different leaf samples } \\
\hline & W & RV & $\mathrm{T}$ & $\mathrm{N}$ & $\mathrm{RV}+\mathrm{T}$ & $\mathrm{RV}+\mathrm{N}$ & $\mathrm{T}+\mathrm{N}$ & $\mathrm{RV}+\mathrm{T}+\mathrm{N}$ & $\mathrm{F}$ \\
\hline Sordariomycetes & 48.9 & 43.3 & 78.4 & 52.5 & 78.1 & 48.6 & 82.5 & 77.9 & 46.0 \\
\hline Dothideomycetes & 19.8 & 22.1 & 8.0 & 19.1 & 7.0 & 22.1 & 3.5 & 8.6 & 16.6 \\
\hline Tremellomycetes & 6.2 & 9.1 & 6.4 & 8.0 & 7.7 & 6.6 & 9.2 & 5.9 & 4.8 \\
\hline Agaricomycetes & 7.5 & 9.4 & 2.7 & 7.0 & 3.0 & 9.3 & 2.3 & 2.3 & 13.7 \\
\hline Leotiomycetes & 4.0 & 4.3 & 1.3 & 3.0 & 1.1 & 4.3 & 1.1 & 1.4 & 5.0 \\
\hline Lecanoromycetes & 4.1 & 4.1 & 0.8 & 3.2 & 1.0 & 2.8 & 0.3 & 0.8 & 3.5 \\
\hline Taphrinomycetes & 2.2 & 2.4 & 1.0 & 2.4 & 0.7 & 2.2 & 0.4 & 0.7 & 3.9 \\
\hline Chytridiomycetes & 2.9 & 1.8 & 0.4 & 2.2 & 0.4 & 1.3 & 0.3 & 1.2 & 1.8 \\
\hline Eurotiomycetes & 1.7 & 1.8 & 0.5 & 1.0 & 0.7 & 1.3 & 0.2 & 0.5 & 3.0 \\
\hline Microbotryomycetes & 0.7 & 0.1 & 0.1 & 0.6 & 0.1 & 0.4 & 0.2 & 0.5 & 0.4 \\
\hline Cystobasidiomycetes & 0.6 & 0.6 & 0.1 & 0.5 & 0.1 & 0.3 & 0.1 & 0.1 & 0.5 \\
\hline Pezizomycetes & 0.2 & 0.1 & 0.1 & 0.2 & 0.1 & 0.2 & 0.0 & 0.1 & 0.2 \\
\hline Pucciniomycetes & 0.1 & 0.6 & 0.0 & 0.1 & 0.0 & 0.1 & 0.1 & 0.1 & 0.2 \\
\hline Shannon-Wiener diversity index & 1.699 & 1.731 & 0.898 & 1.577 & 0.890 & 1.612 & 0.735 & 0.947 & 1.743 \\
\hline Simpson diversity index & 0.707 & 0.742 & 0.375 & 0.675 & 0.378 & 0.699 & 0.313 & 0.387 & 0.733 \\
\hline$P^{\mathrm{c}}$ & $\ldots$ & 0.164 & $<0.001 *$ & 0.714 & $<0.001 *$ & 0.594 & $<0.001 *$ & $<0.001 *$ & 0.816 \\
\hline
\end{tabular}

a Average number of sequences per sample was 1,475 \pm 440 . Treatments: $\mathrm{W}=$ water, $\mathrm{RV}=\mathrm{RhizoVital} 42 \mathrm{fl}$., $\mathrm{T}=\mathrm{Trianum}-\mathrm{P}, \mathrm{N}=\mathrm{Naturalis}$, and $\mathrm{F}=\mathrm{fungicides}$.

${ }^{b}$ Internal transcribed spacer ribosomal RNA (ITS rRNA) sequences assigned to fungal classes (classes with $>1 \%$ in total are displayed).

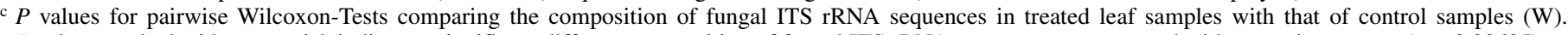

$P$ values marked with an asterisk indicate a significant different composition of fungal ITS rRNA sequences as compared with control treatment $(\alpha=0.00625)$. 
single-strain treatment did $(P<0.001)$. The indices for biodiversity appeared to be similar when comparing control samples with BCA-treated samples at the third sampling date. For the fungicide-treated leaf samples, the Shannon-Wiener and Simpson diversity indices ( 1.715 and 0.755 , respectively) were $\approx 1.5$-fold higher than those of the control samples (1.144 and 0.540, respectively). The composition of fungi, however, was not significantly affected by fungicide treatments $(P=0.199)$.

By means of PCA, the samples could be grouped according to their fungal composition (Fig. 4A and C), confirming the effects of Trichoderma spp. treatments on the indigenous fungal community in the phyllosphere of field-grown strawberry. Grouping of Trichoderma spp.-treated leaf samples was strongly correlated with the high loading of members of class Sordariomycetes at the second sampling date (Fig. 4B), whereas it was correlated with the loadings of members of classes Tremellomycetes and Sordariomycetes at the third sampling date (Fig. 4D). In the samples treated with Trianum-P, the relative abundance of class Sordariomycetes was strongly enhanced at the second and third sampling dates. Having a closer look into that class, the relative abundance of ITS rRNA sequences assigned to the family of Hypocreaceae (comprising the genus Trichoderma) was also strongly increased in these leaf samples (Fig. 5). The abundance of Hypocreaceae sequences was also increased in Naturalistreated leaf samples at the third sampling date.

Comparing only the control samples, the composition of fungal communities differed between the three sampling dates. The relative abundance of class Sordariomycetes, for instance, increased from $7.2 \%$ at the first sampling (BBCH 59) to $48.9 \%$ at the second sampling (BBCH 65) and, thereafter, decreased to $6.2 \%$ at the third sampling date (BBCH 78). In contrast, the relative abundance of class Tremellomycetes decreased from 57.3 to $6.2 \%$ at the second sampling and, thereafter, increased to $63.6 \%$ at the third sampling date (Tables 2 to 4 ).

Composition and biodiversity of bacterial classes among different samples. Comparing the $16 \mathrm{~S}$ rRNA profiles at class level prior to BCA introduction (22 April 2010; $\mathrm{BBCH} 59$ ), composition of bacterial communities did not significantly differ among the leaf samples (Table 5). Strawberry phyllosphere was mainly colonized by members of classes Alphaproteobacteria, Actinobacteria, Cytophagia, and Betaproteobacteria. The ShannonWiener diversity index in leaf samples intended for subsequent fungicide treatments was decreased by $\approx 50 \%$ as compared with control samples. However, the composition of bacteria (class level) within fungicide-treated samples $(P=0.016)$ was not significantly different from control samples.

After the application of BCAs, bacterial communities of the strawberry phyllosphere mainly consisted of members of classes Actinobacteria, Alphaproteobacteria, and Betaproteobacteria at the second sampling date (11 May 2010; BBCH 65). The Shannon-Wiener and Simpson diversity indices were similar ( 1.420 to 1.670 and 0.682 to 0.763 , respectively) across all samples (Table 6). Also, the composition of bacteria (class level) was not affected by applications of either BCAs or fungicides. At the third sampling date (27 May 2010; BBCH 78), bacterial communities on strawberry leaves were composed of members of Alphaproteobacteria as the main class, plus members of Gammaproteobacteria, Cytophagia, Actinobacteria, and Betaproteobacteria. Even though the Shannon-Wiener and Simpson diversity indices were 1.357 to 2.067 and 0.625 to 0.828 , respectively, among the different leaf samples, the bacterial communities at class level were, again, not significantly changed after applications of BCAs or fungicides (Table 7). Accordingly, the relative abundance of 16S rRNA sequences assigned to the class of Bacilli was not higher in bacilli-treated leaf samples than in control samples at either the second or third sampling date. At the second sampling date, the relative abundance of class Bacilli was even higher in control $(11.8 \%)$ and fungicide-treated samples $(13 \%)$ than in samples treated with RhizoVital 42 fl. (2.8\%), RhizoVital 42 fl. + Trianum-P (5.2\%), RhizoVital 42 fl. + Naturalis $(2.7 \%)$, and RhizoVital 42 fl.+ Trianum-P + Naturalis (3.0\%).

The bacterial composition also differed in the control samples obtained at different sampling dates. For instance, the relative abundance of class Alphaproteobacteria was similar at the first and second sampling dates $(\mathrm{BBCH} 59$ and $\mathrm{BBCH}$ 65, respectively) but, thereafter, increased from 29.4 to $53.7 \%$ at the third sampling date (BBCH 78). Similarly, the relative abundance of class Actinobacteria was 32.7 and $41.2 \%$ at the first and second sampling dates, whereas it decreased to $10.3 \%$ at the third sampling date (Tables 5 to 7).

\section{DISCUSSION}

To date, various studies have revealed that the composition of leaf microbiota can be affected by a wide range of biotic and abiotic factors, such as plant species (49), pathogen infections (42), cropping systems $(31,39)$, pesticide use $(46,50,52)$, geographical location $(13,33)$, and other environmental conditions

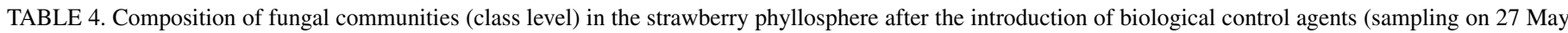
$2010 ; \mathrm{BBCH} 78)^{\mathrm{a}}$

\begin{tabular}{|c|c|c|c|c|c|c|c|c|c|}
\hline \multirow[b]{2}{*}{ Fungal classes ${ }^{b}$} & \multicolumn{9}{|c|}{ Relative abundance of fungal classes $(\%)$ in different leaf samples } \\
\hline & $\mathrm{W}$ & RV & $\mathrm{T}$ & $\mathrm{N}$ & $\mathrm{RV}+\mathrm{T}$ & $\mathrm{RV}+\mathrm{N}$ & $\mathrm{T}+\mathrm{N}$ & $\mathrm{RV}+\mathrm{T}+\mathrm{N}$ & $\mathrm{F}$ \\
\hline Tremellomycetes & 63.6 & 61.0 & 54.1 & 63.7 & 53.6 & 68.1 & 66.4 & 66.2 & 38.8 \\
\hline Sordariomycetes & 6.2 & 5.7 & 20.6 & 23.1 & 35.8 & 6.3 & 21.1 & 24.3 & 13.8 \\
\hline Dothideomycetes & 22.2 & 21.1 & 14.4 & 7.9 & 7.5 & 15.8 & 7.8 & 6.3 & 25.2 \\
\hline Microbotryomycetes & 2.4 & 3.5 & 1.3 & 2.2 & 1.9 & 2.1 & 2.8 & 0.9 & 4.2 \\
\hline Agaricomycetes & 1.5 & 3.0 & 1.8 & 0.6 & 0.2 & 1.7 & 0.2 & 0.8 & 9.4 \\
\hline Taphrinomycetes & 1.3 & 1.7 & 2.4 & 0.5 & 0.2 & 2.6 & 0.7 & 0.3 & 0.4 \\
\hline Leotiomycetes & 0.9 & 0.5 & 1.1 & 0.3 & 0.0 & 0.7 & 0.5 & 0.2 & 2.7 \\
\hline Cystobasidiomycetes & 0.8 & 0.8 & 1.0 & 0.5 & 0.8 & 1.1 & 0.0 & 0.2 & 1.1 \\
\hline Eurotiomycetes & 0.5 & 1.3 & 0.3 & 0.3 & 0.0 & 0.0 & 0.5 & 0.2 & 2.1 \\
\hline Lecanoromycetes & 0.1 & 0.3 & 0.8 & 0.2 & 0.0 & 0.4 & 0.0 & 0.2 & 0.8 \\
\hline Agaricostilbomycetes & 0.2 & 0.2 & 0.6 & 0.5 & 0.0 & 0.7 & 0.0 & 0.3 & 0.2 \\
\hline Wallemiomycetes & 0.1 & 0.0 & 0.3 & 0.2 & 0.0 & 0.3 & 0.0 & 0.0 & 1.0 \\
\hline Chytridiomycetes & 0.0 & 0.3 & 1.0 & 0.0 & 0.0 & 0.1 & 0.0 & 0.0 & 0.0 \\
\hline Shannon-Wiener diversity index & 1.144 & 1.279 & 1.414 & 1.092 & 1.035 & 1.145 & 0.999 & 0.969 & 1.715 \\
\hline Simpson diversity index & 0.540 & 0.576 & 0.642 & 0.536 & 0.578 & 0.506 & 0.508 & 0.500 & 0.755 \\
\hline$P^{\mathrm{c}}$ & $\ldots$ & 0.670 & 0.194 & $<0.001 *$ & $<0.001 *$ & 0.423 & 0.008 & $<0.001 *$ & 0.199 \\
\hline
\end{tabular}

a Average number of sequences per sample was $629 \pm 122$. Treatments: $\mathrm{W}=$ water, $\mathrm{RV}=\mathrm{Rhizo}$ Vital $42 \mathrm{fl}$., $\mathrm{T}=\mathrm{Trianum}-\mathrm{P}, \mathrm{N}=\mathrm{Naturalis}$, and $\mathrm{F}=$ fungicides.

${ }^{\mathrm{b}}$ Internal transcribed spacer ribosomal RNA (ITS rRNA) sequences assigned to fungal classes (classes with $>1 \%$ in total are displayed).

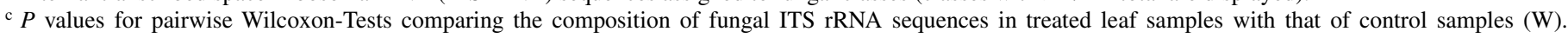

$P$ values marked with an asterisk indicate a significant different composition of fungal ITS rRNA sequences as compared with control treatment $(\alpha=0.00625)$. 
$(13,19,33)$. Although possible effects of BCAs on nontarget microorganisms are important issues in terms of environmental safety (7), only very few investigations have been conducted addressing the potential interactions between introduced BCAs and indigenous microbial communities in the phyllosphere $(20,30,35,51)$. The use of BCAs was intensively studied in strawberry $(12,14,17,40)$. Therefore, strawberry represents an ideal model crop with which to study the effects of BCAs on the leaf microbiota.

In the present study, we investigated whether the indigenous leaf microbiota in field-grown strawberry is affected by introducing BCAs to foliar plant parts. The impact of three BCAsnamely, RhizoVital 42 fl. (Bacillus amyloliquefaciens FZB42), Trianum-P (T. harzianum T22), and Naturalis (Beauveria bassiana ATCC 74040)—on the indigenous phyllosphere microorganisms was analyzed using plate counts and pyrosequencing.

Phyllosphere microbial communities are driven by immigration, colonization, and emigration of microorganisms. These processes, in turn, are affected by environmental conditions and

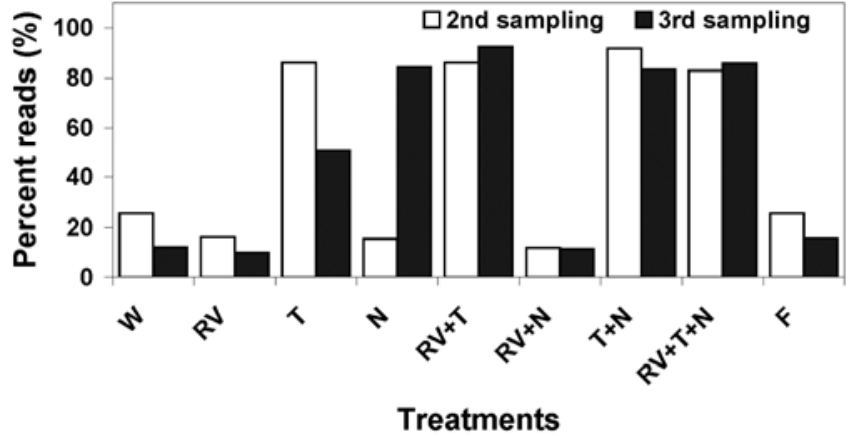

Fig. 5. Relative abundance (\%) of internal transcribed spacer ribosomal RNA (ITS rRNA) sequences assigned to the family of Hypocreaceae for different strawberry leaf samples after the introduction of biological control agents (second sampling date: 11 May 2010; BBCH 65; third sampling date: 27 May 2010; BBCH 78). Treatments are indicated by $\mathrm{W}=$ water, $\mathrm{RV}=$ RhizoVital $42 \mathrm{fl}$., $\mathrm{T}=$ Trianum- $\mathrm{P}, \mathrm{N}=$ Naturalis, and $\mathrm{F}=$ fungicides.
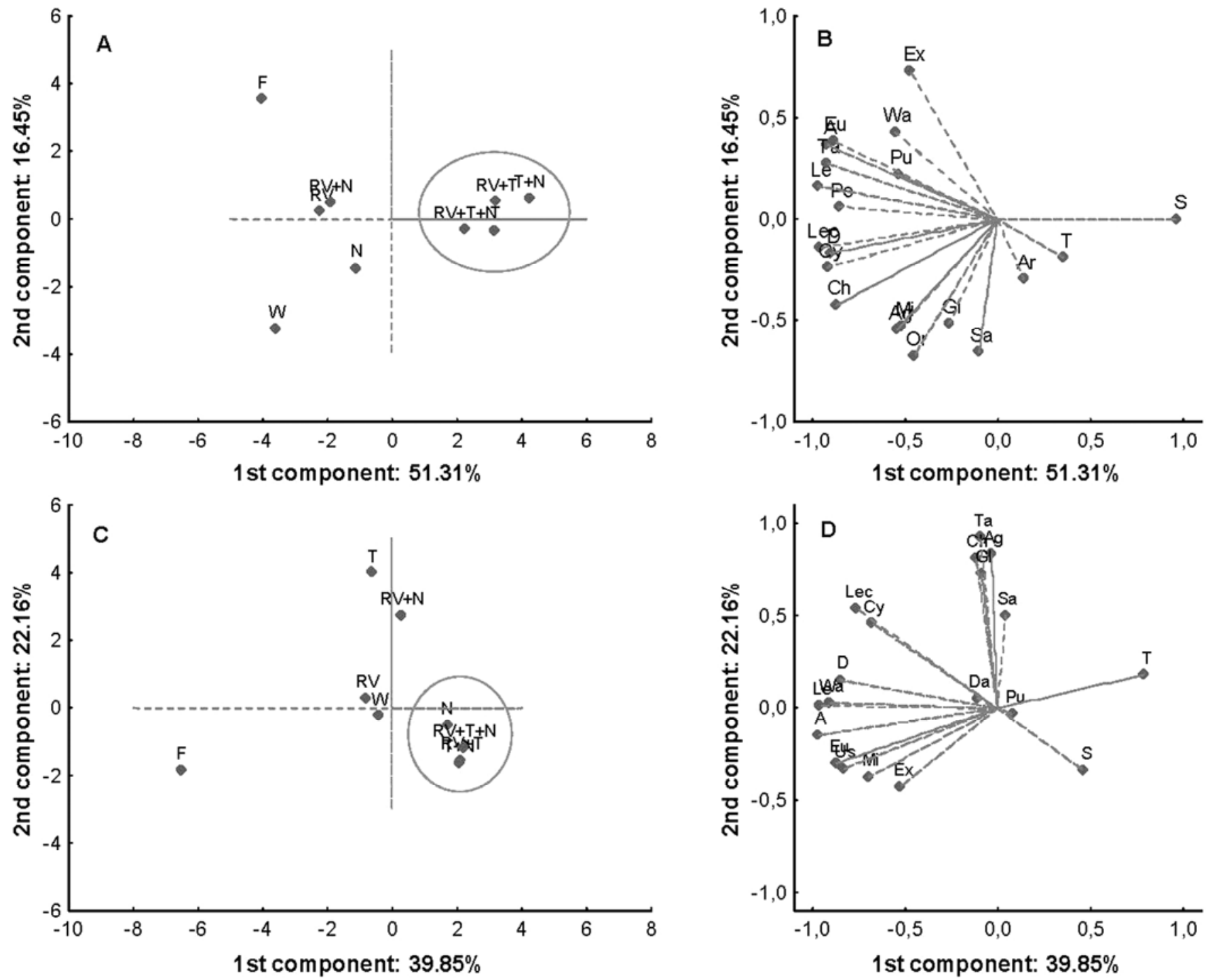

Fig. 4. Principal component analyses based on internal transcribed spacer ribosomal RNA (ITS rRNA) sequences (percentage reads, class level) for different strawberry leaf samples after the introduction of biological control agents at $\mathbf{A}$ and $\mathbf{B}$, the second sampling date (11 May 2010; BBCH 65) and $\mathbf{C}$ and $\mathbf{D}$, the third sampling date (27 May 2010; $\mathrm{BBCH} 78$ ). Treatments are indicated by $\mathrm{W}=$ water, $\mathrm{RV}=$ RhizoVital $42 \mathrm{fl} ., \mathrm{T}=\mathrm{Trianum}-\mathrm{P}, \mathrm{N}=\mathrm{Naturalis}$, and $\mathrm{F}=$ fungicides . Treatments in whose fungal composition significantly differed from that in control samples are encircled in score plots (A and C). In the loading plots (B and D), variables are indicated by $\mathrm{A}=$ Agaricomycetes, $\mathrm{Ag}=$ Agaricostilbomycetes, $\mathrm{Ar}=$ Arthoniomycetes $, \mathrm{Ch}=\mathrm{Chytridiomycetes}, \mathrm{Cy}=\mathrm{Cystobasidiomycetes}, \mathrm{D}=$ Dothideomycetes; $\mathrm{Da}=$ Dacrymycetes, $\mathrm{Eu}=$ Eurotiomycetes, $\mathrm{Ex}=$ Exobasidiomycetes, $\mathrm{Gl}=$ Glomeromycetes, Le $=$ Leotiomycetes, Lec $=\mathrm{Lecanoromycetes}$, $\mathrm{Mi}=$ Microbotryomycetes, $\mathrm{Or}=$ Orbiliomycetes, $\mathrm{Pe}=$ Pezizomycetes, $\mathrm{Pu}=$ Pucciniomycetes, $\mathrm{S}=$ Sordariomycetes, $\mathrm{Sa}=\mathrm{Saccharomycetes}, \mathrm{T}=\mathrm{Tremellomycetes}$, $\mathrm{Ta}=$ Taphrinomycetes, Us $=$ Ustilaginomycetes, and Wa $=$ Wallemiomycetes. 
leaf surface characteristics (e.g., nutrient availability and cuticle) but also by the plant genotype and the resident microorganisms of the phyllosphere $(28,29,48)$. In this context, the ability of the immigrating microorganism to tolerate or to adapt to the phyllosphere environment (e.g., aggregate formation, habitat modification, motility, release of surfactants, or production of UV-protecting pigments) accounts for its competitiveness and, therefore, might be crucial for its establishment in this relatively harsh habitat $(2,8,22,24,25,48)$. However, very little knowledge is available about the ecological concept of stability for indigenous microbial communities after perturbations in the phyllosphere, such as the application of BCAs (28).

According to plate counts, the indigenous leaf microbiota of field-grown strawberry seemed to be dominated by bacteria rather than by fungi throughout the season. These findings are in accordance with results of Krimm et al. (22), who found that fungal isolates only made up $4 \%$ of the culturable leaf microbiota in field-grown strawberry as compared with $28 \%$ in greenhousegrown ones. It is assumed that bacteria are more competitive in the hostile environment of the phyllosphere than filamentous fungi (1), mainly due to their ability to adapt to this habitat $(24,48)$.

Although it might be tempting to draw conclusions from pyrosequencing on the abundance of fungi and bacteria in the phyllosphere, the higher numbers of fungal ITS rRNA sequences might have technical causes because fragments of fungal ITS rRNA and 16S rRNA were sequenced on the same plate. Both methods, however, revealed that the composition of microbial

TABLE 5. Composition of bacterial communities (class level) in the strawberry phyllosphere prior to the introduction of biological control agents (sampling on 22 April 2010; BBCH 59) ${ }^{\mathrm{a}}$

\begin{tabular}{|c|c|c|c|c|c|c|c|c|c|}
\hline \multirow[b]{2}{*}{ Bacterial classes $^{b}$} & \multicolumn{9}{|c|}{ Relative abundance of bacterial classes $(\%)$ in different leaf samples } \\
\hline & W & RV & $\mathrm{T}$ & $\mathrm{N}$ & $\mathrm{RV}+\mathrm{T}$ & $\mathrm{RV}+\mathrm{N}$ & $\mathrm{T}+\mathrm{N}$ & $\mathrm{RV}+\mathrm{T}+\mathrm{N}$ & $\mathrm{F}$ \\
\hline Alphaproteobacteria & 28.2 & 35.3 & 32.0 & 22.7 & 29.5 & 20.0 & 33.3 & 30.9 & 71.2 \\
\hline Actinobacteria & 32.7 & 35.3 & 38.0 & 27.3 & 35.8 & 30.0 & 40.5 & 29.4 & 11.6 \\
\hline Cytophagia & 14.5 & 8.8 & 10.0 & 27.3 & 8.3 & 10.0 & 7.1 & 8.8 & 13.3 \\
\hline Betaproteobacteria & 2.7 & 1.5 & 4.0 & 4.5 & 8.8 & 20.0 & 7.1 & 17.6 & 1.5 \\
\hline Bacilli & 2.7 & 4.4 & 2.0 & 9.1 & 3.1 & 6.7 & 4.8 & 4.4 & 0.2 \\
\hline Gammaproteobacteria & 6.4 & 4.4 & 2.0 & 0.0 & 1.6 & 3.3 & 2.4 & 4.4 & 1.0 \\
\hline Deltaproteobacteria & 0.9 & 2.9 & 4.0 & 4.5 & 3.6 & 6.7 & 0.0 & 1.5 & 0.3 \\
\hline Acidobacteria & 3.6 & 1.5 & 2.0 & 0.0 & 4.7 & 0.0 & 2.4 & 1.5 & 0.0 \\
\hline Sphingobacteria & 1.8 & 0.0 & 0.0 & 4.5 & 1.0 & 0.0 & 0.0 & 1.5 & 0.0 \\
\hline Clostridia & 2.7 & 0.0 & 4.0 & 0.0 & 0.5 & 0.0 & 0.0 & 0.0 & 0.0 \\
\hline Erysipelotrichi & 0.0 & 0.0 & 0.0 & 0.0 & 0.5 & 3.3 & 0.0 & 0.0 & 0.0 \\
\hline Deinococci & 0.9 & 1.5 & 0.0 & 0.0 & 0.5 & 0.0 & 0.0 & 0.0 & 0.7 \\
\hline Caldilineae & 0.0 & 0.0 & 0.0 & 0.0 & 0.5 & 0.0 & 2.4 & 0.0 & 0.0 \\
\hline Gemmatimonadetes & 0.0 & 0.0 & 2.0 & 0.0 & 0.5 & 0.0 & 0.0 & 0.0 & 0.0 \\
\hline Anaerolineae & 0.9 & 1.5 & 0.0 & 0.0 & 0.0 & 0.0 & 0.0 & 0.0 & 0.0 \\
\hline Planctomycetacia & 0.9 & 1.5 & 0.0 & 0.0 & 0.0 & 0.0 & 0.0 & 0.0 & 0.0 \\
\hline Verrucomicrobiae & 0.0 & 1.5 & 0.0 & 0.0 & 0.0 & 0.0 & 0.0 & 0.0 & 0.0 \\
\hline Thermomicrobia & 0.9 & 0.0 & 0.0 & 0.0 & 0.0 & 0.0 & 0.0 & 0.0 & 0.2 \\
\hline Shannon-Wiener diversity index & 1.877 & 1.704 & 1.662 & 1.683 & 1.811 & 1.823 & 1.522 & 1.706 & 0.946 \\
\hline Simpson diversity index & 0.783 & 0.738 & 0.737 & 0.785 & 0.765 & 0.809 & 0.711 & 0.775 & 0.462 \\
\hline$P^{\mathrm{c}}$ & $\ldots$ & 0.820 & 0.9545 & 0.778 & 0.777 & 0.496 & 0.865 & 0.221 & 0.016 \\
\hline
\end{tabular}

a Average number of sequences per sample was $233 \pm 178$. Treatments: $\mathrm{W}=$ water, $\mathrm{RV}=\mathrm{Rhizo}$ Vital $42 \mathrm{fl}$., $\mathrm{T}=\mathrm{Trianum}-\mathrm{P}, \mathrm{N}=\mathrm{Naturalis}$, and $\mathrm{F}=$ fungicides.

b $16 \mathrm{~S}$ ribosomal (r)RNA sequences assigned to bacterial classes (classes with $>1 \%$ in total are displayed).

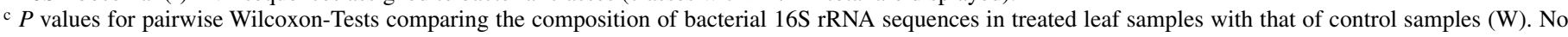
significant differences were evident in the composition of fungal ITS rRNA sequences as compared with control samples $(\alpha=0.00625)$.

TABLE 6. Composition of bacterial communities (class level) in the strawberry phyllosphere after the introduction of biological control agents (sampling on 11 May 2010; BBCH 65) ${ }^{\mathrm{a}}$

\begin{tabular}{|c|c|c|c|c|c|c|c|c|c|}
\hline \multirow[b]{2}{*}{ Bacterial classes $^{b}$} & \multicolumn{9}{|c|}{ Relative abundance of bacterial classes $(\%)$ in different leaf samples } \\
\hline & $\mathrm{W}$ & RV & $\mathrm{T}$ & $\mathrm{N}$ & $\mathrm{RV}+\mathrm{T}$ & $\mathrm{RV}+\mathrm{N}$ & $\mathrm{T}+\mathrm{N}$ & $\mathrm{RV}+\mathrm{T}+\mathrm{N}$ & $\mathrm{F}$ \\
\hline Actinobacteria & 41.2 & 42.3 & 42.9 & 29.3 & 31.3 & 38.0 & 42.3 & 37.6 & 32.2 \\
\hline Alphaproteobacteria & 29.4 & 28.2 & 27.5 & 31.7 & 22.2 & 29.3 & 28.8 & 32.7 & 23.2 \\
\hline Betaproteobacteria & 3.3 & 2.8 & 6.6 & 12.2 & 7.3 & 4.7 & 2.3 & 4.9 & 12.6 \\
\hline Cytophagia & 2.6 & 4.2 & 3.3 & 14.6 & 3.8 & 6.0 & 7.4 & 3.8 & 4.2 \\
\hline Deltaproteobacteria & 3.9 & 8.5 & 3.3 & 4.9 & 5.6 & 6.7 & 3.7 & 7.6 & 5.1 \\
\hline Gammaproteobacteria & 2.6 & 2.8 & 4.4 & 0.0 & 20.8 & 6.0 & 3.7 & 3.0 & 5.6 \\
\hline Bacilli & 11.8 & 2.8 & 1.1 & 2.4 & 5.2 & 2.7 & 3.3 & 3.0 & 13.0 \\
\hline Acidobacteria & 1.3 & 2.8 & 3.3 & 2.4 & 1.4 & 3.3 & 3.7 & 3.4 & 1.6 \\
\hline Sphingobacteria & 0.7 & 2.8 & 4.4 & 2.4 & 0.7 & 2.0 & 2.3 & 0.8 & 0.6 \\
\hline Clostridia & 1.3 & 1.4 & 0.0 & 0.0 & 0.8 & 0.0 & 0.9 & 0.8 & 0.6 \\
\hline Gemmatimonadetes & 0.7 & 1.4 & 0.0 & 0.0 & 0.1 & 0.0 & 0.5 & 0.0 & 0.0 \\
\hline Thermomicrobia & 0.0 & 0.0 & 1.1 & 0.0 & 0.0 & 0.7 & 0.0 & 0.4 & 0.4 \\
\hline Flavobacteria & 0.0 & 0.0 & 0.0 & 0.0 & 0.0 & 0.7 & 0.0 & 1.5 & 0.1 \\
\hline Caldilineae & 0.0 & 0.0 & 1.1 & 0.0 & 0.2 & 0.0 & 0.5 & 0.0 & 0.0 \\
\hline Planctomycetacia & 0.0 & 0.0 & 1.1 & 0.0 & 0.2 & 0.0 & 0.0 & 0.0 & 0.0 \\
\hline Shannon-Wiener diversity index & 1.537 & 1.670 & 1.543 & 1.486 & 1.420 & 1.507 & 1.611 & 1.565 & 1.489 \\
\hline Simpson diversity index & 0.748 & 0.763 & 0.730 & 0.727 & 0.682 & 0.732 & 0.759 & 0.728 & 0.724 \\
\hline$P^{\mathrm{c}}$ & $\ldots$ & 0.511 & 0.403 & 1.000 & 0.447 & 0.798 & 0.842 & 0.710 & 0.197 \\
\hline
\end{tabular}

${ }^{a}$ Average number of sequences per sample was $285 \pm 299$. Treatments: $\mathrm{W}=$ water, $\mathrm{RV}=\mathrm{Rhizo}$ Vital $42 \mathrm{fl}$., $\mathrm{T}=\mathrm{Trianum}-\mathrm{P}, \mathrm{N}=\mathrm{Naturalis}$, and $\mathrm{F}=$ fungicides.

b $16 \mathrm{~S}$ ribosomal (r)RNA sequences assigned to bacterial classes (classes with $>1 \%$ in total are displayed).

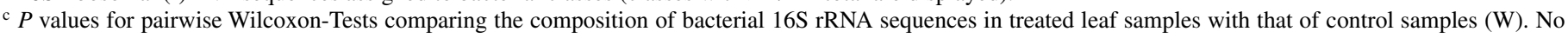
significant differences were evident in the composition of bacterial $16 \mathrm{~S}$ rRNA sequences as compared with control treatment $(\alpha=0.00625)$. 
communities changed throughout the season in the control leaf samples. This finding confirms overall observed seasonal variations in microbial communities $(36,38)$. Seasonal changes in microbial phyllosphere communities might be explained by environmental events (e.g., rainfall) but also by the overall changes of environmental conditions and leaf surface characteristics (e.g., erosion of cuticle and nutrient exudation) as well as plant physiological changes in the course of the season (48).

In the present study, three BCAs were introduced to the phyllosphere to investigate their impact on the stability of the indigenous microbial communities. Applications with the Bacillus-based product RhizoVital $42 \mathrm{fl}$. and the Trichoderma-based product Trianum-P as single-strain or multiple-strain treatments mostly resulted in increased plate counts of endospore-forming bacteria and Trichoderma spp., respectively. However, no clear effects by the introduced BCA on the indigenous leaf microbiota could be detected by this plate count technique. Russell et al. (35) also used plate count technique to study the effect of Bacillus thuringiensis on the leaf microflora of brussels sprout. Likewise, no effects could be detected in their study. The entire leaf microbiota cannot be reflected sufficiently by means of culturedependent techniques $(32,49)$, suggesting that plate counts should not be the exclusive method for studying potential effects on microbial communities caused by introducing BCAs (48).

According to pyrosequencing results, treatments with RhizoVital 42 fl. (B. amyloliquefaciens FZB42) and the Beauveria-based product Naturalis (Beauveria bassiana ATCC 74040) did not affect the composition and biodiversity of the indigenous phyllosphere fungi and bacteria at class level. Similarly, Kim et al. (20) did not observe any effect of foliar treatments with two Bacillus subtilis strains on microbial communities in the phyllosphere of field-grown hot pepper. Based on plate counts and pyrosequencing, it can be assumed that the applied Beauveria bassiana strain was not able to colonize the leaf surface and emigrated from the phyllosphere (for instance, through wash-off or removal by insects) (48) or that this strain was able to avoid the hostile leaf surface by growing inside internal leaf tissues $(2,24)$, where it could develop endophytically $(43,45)$.

In the case of the applied Bacillus strain, the low relative abundance of $16 \mathrm{~S}$ rRNA sequences that could be assigned to the class Bacilli in bacilli-treated leaf samples might suggest that this strain also failed to immigrate into the leaf surface and, as a consequence, emigrated from the phyllosphere. Plate counts, however, revealed that endospore-forming bacteria were enriched in bacilli-treated leaf samples. Thus, the introduced Bacillus amyloliquefaciens FZB42 immigrated into the phyllosphere of strawberry and at least survived as endospores under field conditions without disturbance or displacement of the indigenous microorganisms. Accordingly, we suggest that the applied Bacillus strain endured the harsh environmental conditions in the strawberry phyllosphere by the formation of endospores. This, however, needs to be confirmed in separate future experiments.

Further pyrosequencing results revealed that foliar applications of the Trichoderma-based product Trianum-P had no effects on the bacterial composition and biodiversity at class level, although the introduced strain prevailed in the phyllosphere. This finding indicates that, under field conditions, no antibacterial agents were formed by the introduced Trichoderma strain. However, the composition of fungi changed and biodiversity decreased in most Trichoderma spp-treated leaf samples. The displacement of indigenous phyllosphere fungi points to antagonistic effects by this fungal agent. The displacement might be based on the various modes of actions of Trichoderma spp. such as mycoparasitism through enzyme activities (e.g., chitinases), antibiosis, induced resistance, and competition for nutrients and space (11).

Surprisingly, the Trichoderma-based product Trianum-P did not reduce the incidence of Botrytis cinerea, indicating that the target pathogen obviously did not belong to those fungi that have been displaced by the fungal biocontrol agent. However, the ineffectiveness of the applied Trichoderma preparation against $B$. cinerea might not have arisen just from failed antagonism but, most likely, from inefficient delivery of the preparation to the flowers as compared with the dissemination of Trichoderma spp. by honey bees $(4,40)$.

To our knowledge, this is the first report about at least temporary changes in microbial phyllosphere communities caused by foliar applications of BCAs under field conditions. There have been only very few investigations on the interactions between BCAs and indigenous microorganisms in the phyllosphere $(20,51)$. Similarly to the findings of our study, Zhang et al. (51) observed significant changes in bacterial communities in the phyllosphere of greenhouse-grown pepper after the application of Bacillus thuringiensis. Indeed, many more investigations consider potential effects of BCA applications on soil or rhizosphere microbiota than on leaf microbiota $(3,10,15,20,36-38,44)$. Under soil and rhizosphere conditions, the effects of introduced BCAs, if any, were transient. The culture-dependent and culture-independent techniques used in the present study indicate that

TABLE 7. Composition of bacterial communities (class level) in the strawberry phyllosphere after the introduction of biological control agents (sampling on 27 May 2010; BBCH 78) ${ }^{\mathrm{a}}$

\begin{tabular}{|c|c|c|c|c|c|c|c|c|c|}
\hline \multirow[b]{2}{*}{ Bacterial classes ${ }^{b}$} & \multicolumn{9}{|c|}{ Relative abundance of bacterial classes (\%) in different leaf samples } \\
\hline & $\mathrm{W}$ & RV & $\mathrm{T}$ & $\mathrm{N}$ & $\mathrm{RV}+\mathrm{T}$ & $\mathrm{RV}+\mathrm{N}$ & $\mathrm{T}+\mathrm{N}$ & $\mathrm{RV}+\mathrm{T}+\mathrm{N}$ & $\mathrm{F}$ \\
\hline Alphaproteobacteria & 53.7 & 60.0 & 54.0 & 50.0 & 43.3 & 36.0 & 62.5 & 47.4 & 55.0 \\
\hline Gammaproteobacteria & 12.4 & 11.6 & 12.5 & 13.5 & 20.5 & 14.0 & 10.7 & 10.5 & 30.0 \\
\hline Cytophagia & 7.9 & 8.4 & 15.5 & 7.7 & 17.3 & 18.0 & 5.4 & 23.7 & 0.0 \\
\hline Actinobacteria & 10.3 & 5.8 & 4.5 & 11.3 & 13.4 & 16.0 & 5.4 & 15.8 & 5.0 \\
\hline Betaproteobacteria & 12.0 & 12.3 & 12.1 & 11.9 & 2.4 & 12.0 & 10.7 & 0.0 & 10.0 \\
\hline Bacilli & 1.7 & 1.3 & 0.0 & 1.6 & 1.6 & 0.0 & 1.8 & 0.0 & 0.0 \\
\hline Flavobacteria & 0.8 & 0.0 & 1.1 & 0.3 & 1.6 & 0.0 & 0.0 & 2.6 & 0.0 \\
\hline Deltaproteobacteria & 0.4 & 0.0 & 0.0 & 1.3 & 0.0 & 0.0 & 1.8 & 0.0 & 0.0 \\
\hline Sphingobacteria & 0.0 & 0.0 & 0.4 & 0.3 & 0.0 & 2.0 & 0.0 & 0.0 & 0.0 \\
\hline Acidobacteria & 0.0 & 0.0 & 0.0 & 0.0 & 0.0 & 2.0 & 0.0 & 0.0 & 0.0 \\
\hline Thermomicrobia & 0.0 & 0.0 & 0.0 & 0.0 & 0.0 & 0.0 & 1.8 & 0.0 & 0.0 \\
\hline Clostridia & 0.8 & 0.0 & 0.0 & 0.6 & 0.0 & 0.0 & 0.0 & 0.0 & 0.0 \\
\hline Deinococci & 0.0 & 0.6 & 0.0 & 0.3 & 0.0 & 0.0 & 0.0 & 0.0 & 0.0 \\
\hline Shannon-Wiener diversity index & 1.860 & 1.430 & 1.567 & 2.067 & 1.873 & 1.972 & 1.539 & 1.721 & 1.357 \\
\hline Simpson diversity index & 0.740 & 0.625 & 0.691 & 0.787 & 0.800 & 0.828 & 0.637 & 0.764 & 0.656 \\
\hline$P^{\mathrm{c}}$ & $\ldots$ & 0.427 & 0.438 & 0.523 & 0.910 & 0.642 & 0.796 & 0.826 & 0.594 \\
\hline
\end{tabular}

a Average number of sequences per sample was $142 \pm 106$. Treatments: $\mathrm{W}=$ water, $\mathrm{RV}=\mathrm{Rhizo}$ Vital $42 \mathrm{fl}$., $\mathrm{T}=\mathrm{Trianum}-\mathrm{P}, \mathrm{N}=\mathrm{Naturalis}$, and $\mathrm{F}=$ fungicides.

b 16 ribosomal (r)RNA sequences assigned to bacterial classes (classes with $>1 \%$ in total are displayed).

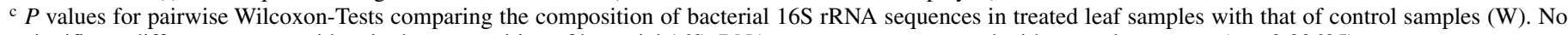
significant differences were evident in the composition of bacterial $16 \mathrm{~S}$ rRNA sequences as compared with control treatment $(\alpha=0.00625)$. 
Trichoderma spp. and members of class Hypocreaceae prevailed during the whole observation period. This might be due to the repeated introduction of BCAs. To draw any final conclusions on displacement of the phyllosphere microbiota caused by the Trichoderma-based product Trianum-P, the observation period needs to become extended, including more samplings after application of BCAs had ceased. Another reason for using this finding of the present study with care is the fact that the causal BCA product Trianum-P is designed and formulated for soil applications (www.koppert.com).

In conclusion, pyrosequencing has shown to be a useful technique for studying nontarget effects of BCAs on indigenous microbial communities. No general concept applies to all of the introduced BCAs. Potential modes of actions of the tested BCAs in the phyllosphere were (i) emigration or avoidance strategy (Beauveria bassiana), (ii) tolerance strategy combined with viable or survival structures (Bacillus amyloliquefaciens), and (iii) displacement strategy with respect to fungal communities (T. harzianum).

However, such explanatory approaches also need to consider the limitations of the methods used in the present study; namely, plate counts as an indicator for culturability and pyrosequencing comprising both viable and dead cells. In this context, metabolomic studies need to be included in forthcoming experiments.

\section{ACKNOWLEDGMENTS}

The project is supported by funds of the Federal Ministry of Food, Agriculture and Consumer Protection (BMELV) based on a decision of the Parliament of the Federal Republic of Germany via the Federal Office for Agriculture and Food (BLE) under the innovation support program. The present study was performed within the framework of the postgraduate school $\mu$ HORT funded by the Swedish research council Formas. We thank ABiTEP GmbH, Koppert Biological Systems, and Intrachem Bio Deutschland $\mathrm{GmbH} \& \mathrm{Co}$. KG for providing the BCA products; D. Becker, Y. Rondot, H. Stegmann, J. Hirsch, and E. Kecskeméti for technical assistance; and the employers from the Institute of Pomology (Geisenheim University) for their support in the field.

\section{LITERATURE CITED}

1. Andrews, J. H., and Harris, R. F. 2000. The ecology and biogeography of microorganisms of plant surfaces. Annu. Rev. Phytopathol. 38:145-180.

2. Beattie, G. A., and Lindow, S. E. 1999. Bacterial colonization of leaves: A spectrum of strategies. Phytopathology 89:353-359.

3. Bernard, E., Larkin, R. P., Tavantzis, S., Erich, M. S., Alyokhin, A., Sewell, G., Lannan, A., and Gross, S. D. 2012. Compost, rapeseed rotation, and biocontrol agents significantly impact soil microbial communities in organic and conventional potato production systems. Appl. Soil Ecol. 52:29-41

4. Bilu, A., Dag, A., Elad, Y., and Shafir, S. 2004. Honey bee dispersal of biocontrol agents: An evaluation of dispensing devices. Biocontrol Sci. Technol. 14:607-617.

5. Brimner, T. A., and Boland, G. J. 2003. A review of the non-target effects of fungi used to biologically control plant diseases. Agric. Ecosyst. Environ. 100:3-16.

6. Buée, M., Reich, M., Murat, C., Morin, E., Nilsson, R. H., Uroz, S., and Martin, F. 2009. 454 Pyrosequencing analyses of forest soils reveal an unexpectedly high fungal diversity. New Phytol. 184:449-456.

7. Cook, J., Bruckart, W. L., Coulson, J. R., Goettel, M. S., Humber, R. A., Lumsden, R. D., Maddox, J. V., McManus, M. L., Moore, L., Meyer, S. F., Quimby, P. C., Stack, J. P., and Vaughn, J. L. 1996. Safety of microorganisms intended for pest and plant disease control: A framework for scientific evaluation. Biol. Control 7:333-351.

8. Delmotte, N., Knief, C., Chaffron, S., Innerebner, G., Roschitzki, B., Schlapbach, R., von Mering, C., and Vorholt J. A. 2009. Community proteogenomics reveals insights into the physiology of phyllosphere bacteria. Proc. Natl. Acad. Sci. USA 106:16428-16433.

9. Droby, S., and Lichter, A. 2004. Post-harvest Botrytis infection: Etiology, development and management. Pages 349-367 in: Botrytis: Biology, Pathology and Control. Y. Elad, B. Williamson, P. Tudzynski, and N. Delen, eds. Springer, The Netherlands.

10. Edel-Hermann, V., Brenot, S., Gautheron, N., Aimé, S., Alabouvette, C., and Steinberg, C. 2009. Ecological fitness of the biocontrol agent $\mathrm{Fu}$ - sarium oxysporum Fo47 in soil and its impact on the soil microbial communities. FEMS Microbiol. Ecol. 68:37-45.

11. Elad, Y. 2000. Biological control of foliar pathogens by means of Trichoderma harzianum and potential modes of action. Crop Prot. 19:709-714.

12. Elad, Y., and Stewart, A.. 2004. Microbial control of Botrytis spp. Pages 223-241 in: Botrytis: Biology, Pathology and Control. Y. Elad, B. Williamson, P. Tudzynski, and N. Delen, eds. Springer, The Netherlands.

13. Finkel, O. M., Burch, A. Y., Lindow, S. E., Post, A. F., and Belkin, S 2011. Geographical location determines the population structure in phyllosphere microbial communities of a salt-excreting desert tree. Appl. Environ. Microbiol. 77:7647-7655.

14. Freeman, S., Minz, D., Kolesnik, I., Barbul, O., Zveibil, A., Maymon, M., Nitzani, Y., Kirshner, B., Rav-David, D., Bilu, A., Dag, A., Shafir, S., and Elad, Y. 2004. Trichoderma biocontrol of Colletotrichum acutatum and Botrytis cinerea and survival in strawberry. Eur. J. Plant Pathol. 110:361370.

15. Gao, G., Yin, D., Chen, S., Xia, F., Yang, J., Li, Q., and Wang, W. 2012. Effect of biocontrol agent Pseudomonas fluorescens 2P24 on soil fungal community in cucumber rhizosphere using T-RFLP and DGGE. PLoS ONE 7:e31806.

16. Hamp, T. J., Jones, W. J., and Fodor, A. A. 2009. Effects of experimental choices and analysis noise on surveys of the "rare biosphere". Appl. Environ. Microbiol. 75:3263-3270.

17. Helbig, J., and Bochow, H. 2001. Effectiveness of Bacillus subtilis (isolate 25021) in controlling Botrytis cinerea in strawberry. J. Plant Dis. Prot. 108:545-559.

18. Hirsch, J., Strohmeier, S., Pfannkuchen, M., and Reineke, A. 2012. Assessment of bacterial endosymbiont diversity in Otiorhynchus spp. (Coleoptera: Curculionidae) larvae using a multitag 454 pyrosequencing approach. BMC Microbiol. 12 (Suppl. 1):S6.

19. Kadivar, H., and Stapleton, A. E. 2003. Ultraviolet radiation alters maize phyllosphere bacterial diversity. Microb. Ecol. 45:353-361.

20. Kim, Y., Cho, M., Jeong, J., Lee, H., and Kim, S. 2010. Application of terminal restriction fragment length polymorphism (T-RFLP) analysis to monitor effect of biocontrol agents on rhizosphere microbial community of hot pepper (Capsicum annuиm L.). J. Microbiol. 48:566-572.

21. Kovach, J., Petzoldt, R., and Harman, G. E. 2000. Use of honey bees and bumble bees to disseminate Trichoderma harzianum 1295-22 to strawberries for Botrytis control. Biol. Control 18:235-242.

22. Krimm, U., Abanda-Nkpwatt, D., Schwab, W., and Schreiber, L. 2005. Epiphytic microorganisms on strawberry plants (Fragaria ananassa cv. Elsanta): Identification of bacterial isolates and analysis of their interaction with leaf surfaces. FEMS Microbiol. Ecol. 53:483-492.

23. Kronstad, J. W. 2000. Infections strategies of Botrytis cinerea and related necrotrophic pathogens Pages 33-64 in: Fungal Pathology. J. W. Kronstad, ed. Kluwer Academic Publishers, Dordrecht, The Netherlands.

24. Lindow, S. E., and Brandl, M. T. 2003. Microbiology of the phyllosphere. Appl. Environ. Microbiol. 69:1875-1883.

25. Lindow, S. E., and Leveau, J. H. J. 2002. Phyllosphere microbiology. Curr. Opin. Biotechnol. 13:238-243.

26. Mäder, R., Liebl, B., and Wilbois, K.-P. 2011. Betriebsmittelliste 2011 für den ökologischen Landbau in Deutschland. Forschungsinstitut für Biologischen Landbau Deutschland e.V., Frankfurt am Main, Germany.

27. Meier, U., Graf, H., Hack, H., Hess, M., Kennel, W., Klose, R., Mappes, D., Seipp, D., Stauss, R., Streif, J., and van den Boom, T. 1994. Phänologische Entwicklungsstadien des Kernobstes (Malus domestica Borkh. und Pyrus communis L.), des Steinobstes (Prunus-Arten), der Johannisbeere (Ribes-Arten) und der Erdbeere (Fragaria $\times$ ananassa Duch.). Nachrichtenbl. Dtsch. Pflanzenschutzd. 46:141-153.

28. Meyer, K. M., and Leveau, J. H. J. 2012. Microbiology of the phyllosphere: A playground for testing ecological concepts. Oecologia 168:621629.

29. Monier, J. M., and Lindow, S. E. 2005. Aggregates of resident bacteria facilitate survival of immigrant bacteria on leaf surfaces. Microbiol. Ecol. 49:343-352.

30. Okon Levy, N., Elad, Y., Katan, J., Baker, S. C., and Faull, J. L. 2006. Trichoderma and soil solarization induced microbial changes on plant surfaces. IOBC/WPRS Bull. 29:21-26.

31. Ottesen, A. R., White, J. R., Skaltsas, D. N., Newell, M. J., and Walsh, C. S. 2009. Impact of organic and conventional management on the phyllosphere microbial ecology of an apple crop. J. Food Prot. 72:2321-2325.

32. Rappe, M. S., and Giovannoni, S. J. 2003. The uncultured microbial majority. Annu. Rev. Microbiol. 57:369-394.

33. Rastogi, G., Sbodio, A., Tech, J. J., Suslow, T. V., Coaker, G. L., and Leveau, J. H. J. 2012. Leaf microbiota in an agroecosystem: Spatiotemporal variation in bacterial community composition on field-grown lettuce. ISME J. 6:1812-1822.

34. Rice, W. R. 1989. Analyzing tables of statistical tests. Evolution 43:223225 .

35. Russell, D., Chard, J., and McKinlay, R. 1999. Effect of Bacillus thurin- 
giensis and a pyrethroid insecticide on the leaf microflora of Brassica oleracea. Lett. Appl. Microbiol. 28:359-362.

36. Savazzini, F., Longa, C. M. O., and Pertot, I. 2009. Impact of the biocontrol agent Trichoderma atroviride $\mathrm{SC} 1$ on soil microbial communities of a vineyard in northern Italy. Soil Biol. Biochem. 41:1457-1465.

37. Scherwinski, K., Grosch, R., and Berg, G. 2008. Effect of bacterial antagonists on lettuce: Active biocontrol of Rhizoctonia solani and negligible, short-term effects on nontarget microorganisms. FEMS Microbiol. Ecol. 64:106-116.

38. Scherwinski, K., Wolf, A., and Berg, G. 2007. Assessing the risk of biological control agents on the indigenous microbial communities: Serratia plymuthica HRO-C48 and Streptomyces sp. HRO-71 as model bacteria. BioControl 52:87-112.

39. Schmid, F., Moser, G., Müller, H., and Berg, G. 2011. Functional and structural microbial diversity in organic and conventional viticulture: Organic farming benefits natural biocontrol agents. Appl. Environ. Microbiol. 77:2188-2191.

40. Shafir, S., Dag, A., Bilu, A., Abu-Toamy, M., and Elad, Y. 2006. Honey bee dispersal of the biocontrol agent Trichoderma harzianum T39: Effectiveness in suppressing Botrytis cinerea on strawberry under field conditions. Eur. J. Plant Pathol. 116:119-128.

41. Shtienberg, D. 2004. Rational management of Botrytis-incited diseases: Integration of control measures and use of warning systems. Pages 335347 in: Botrytis: Biology, Pathology and Control. Y. Elad, B. Williamson, P. Tudzynski, and N. Delen, eds. Springer, The Netherlands.

42. Suda, W., Nagasaki, A., and Shishido, M. 2009. Powdery mildewinfection changes bacterial community composition in the phyllosphere. Microbes Environ. 24:217-223.

43. Tefera, T., and Vidal, S. 2009. Effect of inoculation method and plant growth medium on endophytic colonization of sorghum by the entomo- pathogenic fungus Beauveria bassiana. BioControl 54:663-669.

44. Timms-Wilson, T. M., Kilshaw, K., and Bailey, M. J. 2004. Risk assessment for engineered bacteria used in biocontrol of fungal disease in agricultural crops. Plant Soil 266:57-67.

45. Vega, F. E., Posada, F., Aime, M. C., Pava-Ripoll, M., Infante, F., and Rehner, S. A. 2008. Entomopathogenic fungal endophytes. Biol. Control 46:72-82.

46. Walter, M., Frampton, C. M., Boyd-Wilson, K. S. H., Harris-Virgin, P., and Waipara, N. W. 2007. Agrichemical impact on growth and survival of non-target apple phyllosphere microorganisms. Can. J. Microbiol. 53:4555 .

47. Weber, R. W. S. 2011. Resistance of Botrytis cinerea to multiple fungicides in northern German small-fruit production. Plant Dis. 95:1263-1269.

48. Whipps, J. M., Hand, P., Pink, D., and Bending, G. D. 2008. Phyllosphere microbiology with special reference to diversity and plant genotype. J. Appl. Microbiol. 105:1744-1755.

49. Yang, C. H., Crowley, D. E., Borneman, J., and Keen, N. T. 2001. Microbial phyllosphere populations are more complex than previously realized. Proc. Natl. Acad. Sci. USA 98:3889-3894.

50. Zhang, B., Bai, Z., Hoefel, D., Tang, L., Wang, X., Li, B., Li, Z., and Zhuang, G. 2009. The impacts of cypermethrin pesticide application on the non-target microbial community of the pepper plant phyllosphere. Sci. Total Environ. 407:1915-1922.

51. Zhang, B., Bai, Z., Hoefel, D., Tang, L., Yang, Z., Zhuang, G., Yang, J., and Zhang, H. 2008. Assessing the impact of the biological control agent Bacillus thuringiensis on the indigenous microbial community within the pepper plant phyllosphere. FEMS Microbiol. Lett. 284:102-108.

52. Zhang, B., Zhang, H., Jin, B., Tang, L., Yang, J., Li, B., Zhuang, G., and Bai, Z. 2008. Effect of cypermethrin insecticide on the microbial community in cucumber phyllosphere. J. Environ. Sci. 20:1356-1362. 